\title{
Skadra Margit
}

Szegedi Tudományegyetem

Általános Orvostudományi Kar

Orvosi Szaknyelvi Kommunikációs és Fordítóképző Csoport

\section{A német fogorvosi szaknyelv a harmadiknyelv-elsajátítás tükrében}

\author{
https://doi.org/10.48040/PL.2020.39
}

\begin{abstract}
A Szegedi Tudományegyetem Orvostudományi Karának Orvosi Szaknyelvi Kommunikációs és Forditóképzö Csoportja angol és német nyelvböl is biztosit fogorvosi szaknyelvi kurzusokat a magyar anyanyelvü hallgatóknak. Az elmúlt évek tapasztalati alapján megállapitható, hogy a német szaknyelvre jelentkezö hallgatók jelentös részének az elsö idegen nyelve dominánsan az angol. Többségük a német nyelvet második idegen nyelvként sajátitotta el általános és/vagy középiskolai tanulmányai során. A tanulmány fö célja, hogy bemutassa, milyen hatással van a hallgatók meglévö nyelvismerete a szaknyelvtanulásra, különös tekintettel az angol nyelvtudás befolyására. A tanulmány elsö része a 2019/2020. tanév első félévében német szaknyelvi kurzust végzők nyelvi hátterét mutatja be. Az ehhez szükséges adatokat a hallgatók által kitöltött kérdölvek biztositják, amelyekböl választ kapunk arra, hogy mi az elsö idegen nyelvük, hány nyelven beszélnek, hol tanulták ezeket a nyelveket etc. A tanulmány második fele a hallgatók irásbeli dolgozatait vizsgálva tárja fel, hogy melyek azok a lexikai hibák, amelyek az angol vagy más nyelvek ismeretére vezethetöek vissza.
\end{abstract}

Kulcsszavak: fogorvosi szaknyelv, harmadik nyelv, idegen nyelv, német nyelvoktatás, nyelvelsajátítás

\section{Bevezetés}

Jelen kutatás fő célja feltárni, hogy milyen hatással van(nak) a hallgatók már elsajátított idegen nyelve(i) a német fogorvosi szaknyelvtanulásra. A Szegedi Tudományegyetem Fogorvostudományi Karának hallgatóinak lehetőségük van egyetemi tanulmányaik alatt angol és német fogorvosi szaknyelvi kurzusokra járni. A német fogorvosi szaknyelv tanítása során az elmúlt években szerzett tapasztalataim azt mutatják, hogy a kurzusra jelentkező hallgatók többségének az első idegen nyelve az angol, és ez gyakran kihat az órákon a német nyelvhasználatukra is. Tipikus példái ennek, amikor a német szaknyelvben az angol nyelvre visszavezethető nyelvtani hibákat vétenek, angol szórendet alkalmaznak vagy angol kifejezéseket és szavakat használnak. Ezek a megfigyelések ösztönöztek arra, hogy a harmadiknyelvelsajátítás nézőpontjából elkezdjem vizsgálni a hallgatók német szaknyelvi teljesítményét. 
A tanulmány először rövid áttekintést ad a harmadiknyelv-elsajátítás történetéről, majd ismerteti a kutatás hátterét és módszertanát. Ezután bemutatja a kutatásban részvevő hallgatók nyelvi hátterét, amelyhez az általuk kitöltött kérdöívek nyújtanak segítséget. Ezt követően a kutatásban használt fordítási feladatlap kiértékelésére kerül sor, amelyből megtudhatjuk, hogy az angol nyelv ismerete milyen hatással van a német szaknyelv tanulására, valamint azt, hogy hogyan befolyásolja a hallgatók teljesítményét más nyelvek ismerete vagy az idegennyelv-tudás hiánya. A tanulmány utolsó része azokat a távlati kutatási célokat kívánja meghatározni, amelyek a jövőben elősegíthetik a német fogorvosi szaknyelvoktatás sikeresebbé tételét.

\section{Harmadiknyelv-elsajátítás}

A harmadiknyelv-elsajátítás az alkalmazott nyelvészet viszonylag új tudományterületének számít. Kialakulása Håkan Ringbom The Role of the First Language in Foreign Language Learning címü könyvének 1987-es megjelenéséhez köthető (Ringbom, 1987). A kutatási terület kialakulását az hívta életre, hogy a második nyelv elsajátításának vizsgálata önmagában már nem mindig elegendő, hiszen a mai globális világban az emberek jelentős része többnyelvü, ezáltal egy új nyelv elsajátításakor gyakran nemcsak az anyanyelv ismerte, hanem a további, tanult nyelvek is befolyásolhatják a nyelvelsajátítás folyamatát (Crystal, 1997).

Cenoz (2001) tanulmányában a spanyol, baszk és angol nyelvek egymásra hatását vizsgálta és arra a következtetésre jutott, hogy egy új nyelv elsajátításánál az anyanyelv kevésbé meghatározó tényező abban az esetben, ha a nyelvtanuló már ismer egy olyan nyelvet, amely nyelvileg jobban hasonlít az elsajátítandó nyelvre. De Angelis (2007) tanulmányában felhívja rá a figyelmet, hogy már korábban is tettek hasonló megfigyeléseket az angol, a szuahéli és finn nyelv kapcsán. A finn nyelven beszélök könnyebben sajátítják el a bantu szuahéli nyelvet, ami arra vezethető vissza, hogy mindkét nyelv agglutináló.

A magyar nyelvészek közül T. Balla Ágnes (2012) is a harmadiknyelv-elsajátítást kutatja tanulmányában. Kutatásának egyik kérdése, hogy a magyar diákok angol nyelvi ismeretei milyen mértékben segíthetik a diákot a német szókincs elsajátításában. Az eredményei azt bizonyítják, hogy a diákok angol nyelvtudása segítő szerepet tölt be a német nyelv tanulásakor, azonban nemcsak pozitív, hanem negatív transzfer is létrejöhet a nyelvek között. Jelen kutatás is az angol nyelv német nyelvre gyakorolt hatását vizsgálja, azonban nem általános nyelvi, hanem szaknyelvi kontextusban. 


\section{A kutatás}

Jelen kutatás célja annak vizsgálata, hogy a német szaknyelvórán a hallgatók teljesítményét milyen mértékben befolyásolja a más nyelvekből már meglévő nyelvtudásuk, különös tekintettel az angolra. A korábbi évek szaknyelvtanítási tapasztalatai alapján megállapítható, hogy számos olyan hibát vétenek a hallgatók német nyelvből, amelyek nagy valószínűséggel az angol nyelv ismeretére vezethetőek vissza. Ezek legtöbbször a szókincset érintik, de találkozhatunk ilyen jellegü nyelvtani és pragmatikai hibákkal is. A kutatás a hallgatók német szaknyelvi szókincsére koncentrál és távlati célja egy, a témával foglalkozó kutatássorozat megalapozása.

\section{A kutatás módszertana}

A kutatás két részből áll. A hallgatók a félév elején egy, a nyelvi hátterüket felmérő kérdőívet töltöttek ki. Ebből többek között kiderül, hogy a hallgatók milyen nyelveket tanultak már, rendelkeznek-e nyelvvizsgával, aktív használói-e idegen nyelv(ek)nek. A kutatás második része egy fordítási feladatlapból állt, amelyet a hallgatók a félév második felében írták, miután már szert tettek alapvető szaknyelvi ismeretekre. A válaszadóknak a feladatlapon magyarról németre kellett fordítania mondatokat, amelyekben olyan szavak is szerepeltek, amiket a félév során már elsajátítottak német nyelvböl, és a szavak alakja hasonlít az angol megfelelöjére, például: Lélegezzen az orrán át!; Az apám rákban halt meg.; Önnek fogszuvasodása van.

\section{A kutatás résztvevői}

A hallgatóknak pár év kihagyás után 2010/2011 tanéve óta van ismét lehetőségük a Szegedi Tudományegyetem Orvostudományi Karán német orvosi és fogorvosi szaknyelvet tanulni. A hallgatók heti 1x1,5 órában tanulják a nyelvet. A kurzusra harmad-, negyed- és ötödéves hallgatók jelentkezhetnek, ennek az az oka, hogy az első- és másodéves hallgatók magyar nyelven sem rendelkeznek mindig olyan szaknyelvi ismeretekkel, amelyek alkalmassá tennék őket a szaknyelvtanulásra. Egy elsőéves hallgató még nem ismeri például a fog felépítését, így az olyan magyar szóalakokhoz, mint például pulpa vagy dentin gyakran nem tudnak még jelentést kapcsolni. Ennek azonban megvan az a hátránya, hogy számos esetben olyan hallgatók jelentkeznek harmadévesként a kurzusra, akik előtte a gimnázium óta, tehát akár több éve nem használták aktívan a nyelvet, így a nyelvtudásuk sokszor már megkopott, passzívvá vált. 
A kérdőívet és a fordítási feladatlapot 2019/2020 első félévében a német fogorvosi szaknyelvi kurzusra járó hallgatók töltötték ki. A kutatásban nyolc fö (1 férfi, 7 nő) vett részt, és minden hallgató írásban beleegyezett a részvételbe. A résztvevők anonimitását biztosítandó a hallgatók egy-egy számmal (1-8) lettek a kutatás során jelölve. A kérdöív alapján a hallgatók 21-23 év közöttiek, hat fö harmadéves és két fő negyedéves hallgató. Mindegyikük anyanyelve a magyar. A hallgatók nyelvi elöismereteikre vonatkozó kérdések alapján kiderült, hogy egy hallgató kivételével mindenkinek a német volt az első idegen nyelve. Ez az előző évek tapasztalatival összehasonlítva nem várt csoportösszetétel. A korábbi években a legtöbb hallgatónak a német volt a második idegen nyelve, és az angol nyelv állt az első helyen.

Az 1. táblázat alapján látható, hogy a nyelvvizsgákat figyelembe véve a német és angol nyelv ismerete a domináns, csak egy hallgató rendelkezik latin érettségivel és spanyol nyelvi alapismeretekkel, valamint egy másik hallgató francia alapfokú nyelvtudással. Fontos azonban megemlíteni, hogy minden hallgató rendelkezik latin ismeretekkel is, mivel a fogorvostanhallgatóknak a latin kötelező tantárgy első éven.

1. táblázat. Nyelvvizsga

\begin{tabular}{|c|l|l|l|}
\hline Hallgató\# & Német nyelvvizsga & Angol nyelvvizsga & \multicolumn{1}{c|}{ További nyelvek } \\
\hline 1 & Goethe C1 & $---(\mathrm{B} 2)$ & --- \\
\hline 2 & --- & $---(\mathrm{A} 2)$ & spanyol (A1), latin érettségi \\
\hline 3 & ÖSD B2 & $---(\mathrm{A} 2)$ & --- \\
\hline 4 & TELC B2, C1 & $---(? ? ?)$ & --- \\
\hline 5 & Origo B2 & $---(\mathrm{A} 2)$ & --- \\
\hline 6 & TELC B2 & Origo B2 & --- \\
\hline 7 & BME B2 & $---(\mathrm{A} 2)$ & --- \\
\hline 8 & Origo, Goethe B2 & Origo B2 & francia (A2) \\
\hline
\end{tabular}

A hallgatók német nyelvismeretéről a 2. és 3. táblázat nyújt további információkat.

2. táblázat. Német nyelvismeret

\begin{tabular}{|c|c|c|c|}
\hline Hallgató\# & $\begin{array}{c}\text { Melyik volt az Ön első } \\
\text { idegen nyelve? }\end{array}$ & $\begin{array}{c}\text { Hány évig tanult } \\
\text { németül? }\end{array}$ & $\begin{array}{c}\text { Aktívan használja-e a } \\
\text { német nyelvet? }\end{array}$ \\
\hline 1 & német & 15 & 2 éve nem \\
\hline 2 & német & 12 & igen \\
\hline 3 & német & 12 & 6 éve nem \\
\hline 4 & német & 12 & 4 éve nem \\
\hline 5 & német & 11 & 4,5 éve nem \\
\hline 6 & német & 8 & 7 éve nem \\
\hline 7 & német & 7 & 5 éve nem \\
\hline 8 & angol & 5 & 2 éve nem \\
\hline
\end{tabular}


A hallgatók mindegyike legalább 5 éven át tanult németül, de vannak olyan hallgatók is, akik 12-15 éven keresztül. Az is látható, hogy csak a hallgató\#2 használja aktívan a német nyelvet, a másik hét hallgató azonban nem.

3. táblázat. Milyen keretek között tanult/tanul Ön németül?

\begin{tabular}{|l|c|c|c|c|c|c|c|c|}
\hline Hallgató\#: & $\mathbf{1}$ & $\mathbf{2}$ & $\mathbf{3}$ & $\mathbf{4}$ & $\mathbf{5}$ & $\mathbf{6}$ & $\mathbf{7}$ & $\mathbf{8}$ \\
\hline általános iskola & $\mathrm{X}$ & $\mathrm{X}$ & $\mathrm{X}$ & $\mathrm{X}$ & $\mathrm{X}$ & $\mathrm{X}$ & $\mathrm{X}$ & \\
\hline gimnázium & $\mathrm{X}$ & $\mathrm{X}$ & $\mathrm{X}$ & $\mathrm{X}$ & $\mathrm{X}$ & & $\mathrm{X}$ & $\mathrm{X}$ \\
\hline egyetem & $\mathrm{X}$ & $\mathrm{X}$ & $\mathrm{X}$ & & & & & $\mathrm{X}$ \\
\hline nyelvtanfolyam & & & $\mathrm{X}$ & $\mathrm{X}$ & & & & \\
\hline magántanár & & $\mathrm{X}$ & & & $\mathrm{X}$ & & $\mathrm{X}$ & \\
\hline egyéb & & & & & & $\mathrm{X}^{*}$ & \\
\hline
\end{tabular}

* egyéb: otthon, egyedül

A 3. táblázat mutatja, hogy egy hallgató kivételével (hallgató\#8) mindenki már az általános iskolában kezdte a német nyelv elsajátítását, de szinte mindenki tanult németül a gimnáziumi évei alatt is. Az arra vonatkozó kérdésre, hogy milyen keretek között tanulnak/tanultak németül, csak néhány hallgató adta meg a nyelvtanfolyamot és a magántanárt válaszként, egy hallgató pedig az egyéb kategóriában az egyéni, otthoni tanulást jelölte meg.

\section{A kutatás eredménye}

A fordításra kijelölt mondatok mindegyike tartalmazott egy vagy több olyan szót is, amely a korábbi évek tanítási tapasztalatai alapján jellemzően gondot szokott okozni a hallgatóknak, és amelyeket gyakran helyettesítenek az angol szóalakkal (Karies-caries, Zahnextraktion-tooth extraction, Knie-knee, Vater-father, Krebs-cancer, *crab, Nase-nose, Alkohol-alcohol, Bier-beer). Valamint két olyan szó is szerepelt a mondatokban, amelyet a hallgatók gyakran felcserélnek az angol szóalakkal, annak ellenére, hogy a német és angol szó között nem áll fenn alaktani hasonlóság (Spritze-injection, schnellfast). Több szóalak, mint például a Zahnextraktion vagy az Alkohol a latin nyelvre is visszavezethető, így ezeknél a szavaknál nem lehet teljes bizonyossággal kijelenteni, hogy az angol nyelv ismerete hatott a hallgató szóválasztására.

A fordítási feladatlapon vétett hibákat a 4. táblázat foglalja össze. Ez alapján látható, hogy hallgató\#1 és hallgató\#2 teljesen hibátlan megoldást nyújtott; a két hallgató közül az egyik (hallgató\#1) tanul a leghosszabb ideje németül, a másik (hallgató\#2) az egyetlen a csoportban, aki szaknyelvórán kívül is aktív használója a német nyelvnek. 
4. táblázat. A kutatás eredménye

\begin{tabular}{|c|c|c|c|c|c|c|c|c|}
\hline Szó & \#1 & \#2 & \#3 & \#4 & \#5 & \#6 & \#7 & \#8 \\
\hline Karies & $V$ & $\checkmark$ & $\checkmark$ & Caries & Caries & $\checkmark$ & $\checkmark$ & $\checkmark$ \\
\hline Extraktion & $\nu$ & $\checkmark$ & --- & $\nu$ & --- & Extraction & (Zahnziehen) & Extraction \\
\hline Knie & $V$ & $\checkmark$ & --- & --- & --- & Knee & $\nu$ & Knee \\
\hline Vater & $v$ & $\checkmark$ & 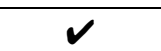 & $\checkmark$ & $\checkmark$ & Fater & $\checkmark$ & $\checkmark$ \\
\hline Krebs & $V$ & $\checkmark$ & $\checkmark$ & $\checkmark$ & $\checkmark$ & $V$ & $\nu$ & $\begin{array}{c}\boldsymbol{V} \\
\text { (eancer) }\end{array}$ \\
\hline Nase & $V$ & $\checkmark$ & --- & --- & --- & --- & $V$ & $\checkmark$ \\
\hline Alkohol & $V$ & $\checkmark$ & $\checkmark$ & $\checkmark$ & Alcohol & Alcohol & Alcohol & $\checkmark$ \\
\hline Bier & $V$ & $\checkmark$ & $\checkmark$ & $V$ & $\checkmark$ & $\checkmark$ & $V$ & Beer \\
\hline Spritze & $V$ & $\checkmark$ & Injekcione & $\checkmark$ & $\checkmark$ & $\checkmark$ & $\checkmark$ & $\checkmark$ \\
\hline schnell & $V$ & $\checkmark$ & $\checkmark$ & --- & fast & $\nu$ & $V$ & $\checkmark$ \\
\hline
\end{tabular}

A táblázat alapján kijelenthető, hogy minél kevesebb ideig tanult valaki németül, annál több hibát vétett a fordításokban. Az a két hallgató vétette a legtöbb hibát, aki angolból rendelkezik középfokú nyelvvizsgával is (hallgató\#6 és hallgató\#8). Azonban fontos kiemelni, hogy mindkét hallgató megoldása érthető a német-angol szóalak hasonlósága miatt - még ha helyesírásában nem is helyes - ezáltal a kommunikációs cél is feltételezhetően megvalósul ezeknél a mondatoknál, hiszen az általuk megadott Extraction, Knee, Fater, Alcohol és Beer szavak nagyban hasonlítanak a helyes német Extraktion, Knie, Vater, Alkohol és Bier szóalakokra. Azok a hallgatók (hallgató\#3, hallgató\#4 és hallgató\#5), akik angol nyelvböl nem rendelkeznek magas szintü nyelvtudással, több esetben nem fordították le egyáltalán a mondatokat, semmilyen alternatív megoldási lehetőséget nem adtak meg például az Extraktion, Knie és Nase szavaknál. Ez alapján megállapítható, hogy habár hallgató\#6 és hallgató\#8 többször nem a német helyesírás szerint adta meg a szavakat, de angol, esetlegesen latin előismereteikre támaszkodva mégis hatékonyabban tudták megoldani a feladatot, mint a többi hallgató. Hallgató\#8-nál egy esetben az is előfordult, hogy elöször az angol szóalakot használta a mondatfordításban (cancer), majd ezt áthúzva módosította a megfelelő német Krebs szóalakra.

A gyors szó lefordítása hat hallgatónak nem okozott problémát, a megfelelő schnell szóalakot használták a mondatban. Egy hallgató (hallgató\#4) nem fordította le a szót, és hallgató\#5 a német szó helyett az angol fast szóalakot adta meg a német mondatban, tehát ennél a példánál teljesen egyértelmüen tetten érhető az angol nyelv hatása a német nyelvre. Ellis és Larsen-Freeman (2016) szerint, azokat a szavakat, amelyeket 
gyakrabban használ a nyelvtanuló az első idegen nyelvben, sokszor átemeli a következő idegen nyelvbe is, amit tanul. Azonban ez fordítva is igaz, egy új idegen nyelven sokat használt szó is bekerülhet tévesen a már korábban elsajátított idegen nyelvbe. Feltételezhetően ez történhetett itt is, és ezzel magyarázható a fast szó használata a német mondatban.

\section{Konklúzió}

A kutatási eredmények alapján megállapítható, hogy az angol nyelvtudás hatással van a német fogorvosi szaknyelvi órákon a hallgatók teljesítményére, még abban az esetben is, ha a hallgató első idegen nyelve a német. A kutatásban részt vevő csoport összetétele meglehetősen egyoldalú. A nyolc hallgatóból hétnek a német az első idegen nyelve, az általános iskolától kezdve tanulta, és az angol nyelvet később kezdte elsajátítani. Mindenképpen szükséges lenne a jövőben olyan csoportösszetétellel is elvégezni a kutatást, ahol a válaszadók nagyobb hányadának az angol az első idegen nyelve. Erre azonban a 2019/2020. tanévben a kurzus hallgatói összetétele nem adott lehetöséget.

Az eredmények alapján azok a hallgatók, akik hosszabb ideje tanultak németül, és/vagy aktív használói a nyelvnek, sikeresebben tudták kitölteni a feladatlapot. Azok, akik angol nyelvből magasabb szinten állnak - igaz, sokszor a német helyett a szó angol megfelelőjét használva - megpróbálták lefordítani a mondatokat, szemben azokkal, akik angolból alacsonyabb szinten állnak. Ök gyakran semmilyen válaszlehetőséget nem adtak, nem állt rendelkezésükre alternatíva, és ezáltal náluk az információ átadása is kevésbé volt sikeres.

Ezen eredmények alapján feltételezhető, hogy fontos és hatékony szerepe lehet a kontrasztív módszerek használatának a német fogorvosi szaknyelvoktatásban, azonban ezek kidolgozásához elöször további, átfogóbb felmérésekre van szükség, ami feltárja a lehetséges pozitív hatások mellett az esetleges negatív velejárókat is.

\section{Hivatkozások}

Cenoz, J. (2001): The effect of linguistic distance, L2 status and age on cross-linguistic influence in third language acquisition. In: Cenoz, J. - Hufeisen, B. - Jessner, U. (ed.): Cross-linguistic influence in third language acquisition: Psycholinguistic perspectives. (2001): Multilingual Matters: Clevedon. DOI: https://doi.org/10.21832/9781853595509

Crystal, D. (1997): Language death. Cambridge University Press: West Nyack

De Angelis, G. (2007): Third or Additional Language Acquisition. Multilingual Matters: Clevedon. DOI: https://doi.org/10.21832/9781847690050 
Ellis, N. C. - Larsen-Freeman, D. (2006): Language Emergence: Implications for Applied Linguistics. Introduction to the Special Issue. Applied Linguistics. 27/4. 558-589. DOI: https://doi.org/10.1093/applin/aml028

Ringbom, H. (1987): The Role of the First Language in Foreign Language Learning. Multilingual Matters: Clevedon

T. Balla, Á. (2012): The role of second language English in the process of learning third language German. PhD értekezés. Szegedi Tudományegyetem - Angol Alkalmazott Nyelvészeti PhD Program: Szeged. Online elérhető: http://doktori.bibl.uszeged.hu/1658/1/T.Balla_Agnes_dissertation.pdf 